\title{
The Role of African Regional Organizations in the Promotion and Protection of Foreign Investment
}

\author{
Erik Denters \\ Vrije Universiteit, Amsterdam, The Netherlands \\ h.m.g.denters@vu.nl \\ Tarcisio Gazzini \\ University of Lausanne, Switzerland \\ Tarcisio.Gazzini@unil.ch
}

\begin{abstract}
A complex, fragmented and heterogeneous network of domestic and international legal instruments promotes and protects foreign investment in Africa. While bilateral treaties seem to be increasingly unpopular, regionalism is clearly on the rise in the continent. The article examines how regional treaties have contributed to upgrade the current regulation of foreign investment. From this perspective, Africa can be seen as a normative laboratory. Regional treaties, most prominently those concluded within the Economic Community of West African States (ECOWAS) and the Southern African Development Community (SADC), contain several important novelties meant to rebalance the rights and obligations of the various stakeholders as well as to safeguard host State policy space. The content of these treaties has been brought more in line with the evolution of international law, especially with regard to the protection of the environment, social and human rights, transparency, corruption, public scrutiny, economic development, and corporate responsibility.
\end{abstract}

\section{Keywords}

Africa - foreign investment - regional organizations - investment treaties - policy space - sustainable development

* Erik Denters is Associate Professor at the Vrije Universiteit Amsterdam. Tarcisio Gazzini is Senior Researcher at the University of Lausanne.

(C) DENTERS AND GAZZINI, 2017 | DOI 10.1163/22119000-12340048

This is an open access article distributed under the terms of the prevailing CC-BY-NC license at the time of publication. 
The crucial role that foreign investment may play in promoting economic growth is undisputed, ${ }^{1}$ especially in Africa. Tellingly, the United Nations (UN) Millennium Declaration contains a unique section on the special needs of Africa - the only continent specifically addressed in the Declaration - in which the role of foreign investment is emphasised. ${ }^{2}$ Such a role is also recognized in the legislation of several African States, such as the Investment Law of Namibia, which includes amongst the objectives of foreign investment 'the promotion of sustainable economic development and growth through the mobilisation and attraction of foreign and domestic investment to enhance economic development, reduce unemployment, accelerate growth and diversify the economy'? ${ }^{3}$

Although the spectacular increase of foreign investment within and to Africa anticipated a couple of years ago ${ }^{4}$ has not materialized yet, due to several reasons including most prominently the still depressed global economic environment and weak commodities prices, ${ }^{5}$ foreign investments are

1 See, for instance, 'Monterrey Consensus of the International Conference on Financing for Development' (Monterrey, Mexico, 18-22 March 2002) UN Doc A/CONF.198/11, ch 1, res 1, annex, para 20.

2 United Nations Millennium Declaration, UNGA Res 55/2 (18 September 2000) para 28 ('We resolve therefore ... [t]o take special measures to address the challenges of poverty eradication and sustainable development in Africa, including debt cancellation, improved market access, enhanced Official Development Assistance and increased flows of Foreign Direct Investment, as well as transfers of technology'). See also Economic Commission for Africa, 'Key Messages of the Second Session of the Africa Regional Forum on Sustainable Development' (Africa Regional Forum on Sustainable Development, Cairo, 17-19 May 2016) para 19(a) <www.uneca.org/sites/default/files/uploaded-documents/ACPC/ARFSD2016/ e1600802_-_key_messages_-_final_-_en.pdf $>$ accessed 17 February 2017. In the literature, see in particular Stephan W Schill, Christian J Tams and Rainer Hofmann (eds), International Investment Law and Development. Bridging the Gap (Edward Elgar 2015).

3 Namibia Investment Promotion Act (2016) preamble <www.mti.gov.na/downloads/ Gazetted\%20Nam\%2oInvestment\%2oPromotion\%2oAct\%202016.pdf > accessed 17 February 2017.

4 See, for instance, UNCTAD, 'Foreign Direct Investment to Africa Maintains Momentum Sustained by Intra-African Flows' (23 June 2014) <http://unctad.org/en/pages/PressRelease .aspx?OriginalVersionID=189> accessed 17 February 2017; African Development Bank, OECD and United Nations Development Programme, African Economic Outlook 2014: Global Value Chains and Africa's Industrialisation (AfDB/OECD/UNDP 2014) ch 2.

5 UNCTAD, World Investment Report 2016. Investor Nationality: Policy Challenges (United Nations 2016) 36-42. 
still expected to offer the continent an unprecedented opportunity to boost its economic development and pursue the objectives indicated in the UN Millennium Declaration. It is therefore crucial for African governments and organizations to develop sound investment policies and to effectively translate them into coherent and coordinated domestic, regional and international legal instruments.

The article discusses the role of African sub-regional organizations have played and continue to play in the promotion and protection of foreign investment. Whereas these organizations have already made important achievements, however heterogeneous, the potential for further developments is remarkable for two main reasons. ${ }^{6}$ On the one hand, the current network of bilateral investment treaties (BITs) concluded amongst African States, and between African States and third States remains rather underdeveloped, irregular and fragmentary. On the other hand, there is a strong belief that a sub-regional and in due time a pan-African - approach, coupled with the progressive harmonization of domestic policies, will maximise the positive impact of foreign investment. $^{7}$

Taking into account the peculiar features of the continent, the article first briefly maps the current framework of investment treaties in the continent (Part 2). It then discusses the shift from trade globalism and investment bilateralism towards regional arrangements that merge both trade and investment regimes. It also explains the intricacies of regionalism across continents, focussing on Africa (Parts 3 and 4). Part 5 considers the rise of regionalism as a third way, alternative to multilateralism and bilateralism, to promote and regulate foreign investment in Africa. The article finally analyses how African regional organisations have responded to the main concerns raised in the last years in relation to foreign investment and the settlement of related disputes, namely the unbalanced character of the rights and obligations contained in investment treaties, the lack of transparency and public scrutiny, and the inadequate safeguards for host State policy space (Part 6).

6 In general, see UNCTAD, 'The Rise of Regionalism in International Investment Policymaking: Consolidation or Complexity?' IIA Issues Note No 3 (June 2013) <http://unctad.org/en/ pages/newsdetails.aspx?OriginalVersionID $=532>$ accessed 17 February 2017.

7 United Nations Economic Commission for Africa (UNECA), African Union and African Development Bank, Assessing Regional Integration in Africa V: Towards an African Continental Free Trade Area (UNECA 2012). 
It is appropriate to start the inquiry by describing the existing network of investment treaties concluded to facilitate, promote and protect foreign investment in Africa, which immediately appears to be rather complex due to two main reasons. On the one hand, the treaties which compose such network are heterogeneous in terms of structure, purposes and content. On the other hand, these treaties cover foreign investment in a rather fragmented manner across the continent and the parties to them frequently overlap.

When discussing the existing network, one must keep in mind the development at the continental level and in particular the adoption, in March 2016, under the auspices of the African Union (AU) of the Pan-African Investment Code. ${ }^{8}$ The Code contains several innovative provisions intended to ensure the sustainable development of the concerned States. It seeks to preserve adequate policy space of host States and introduces investor obligations. In the course of 2016, AU Member States finally agreed to adopt the Code in the form of a model investment treaty.

What follows is an attempt to develop a taxonomy of treaties promoting and protecting foreign investment in Africa. Treaties have been divided into bilateral and multilateral treaties (respectively section 2.1 and 2.2) and then in a few subcategories.

\section{1}

\section{Bilateral Agreements}

2.1.1

Bilateral Investment Treaties

The current network of investment treaties consists in the first place of BITs. ${ }^{9}$ According to the United Nations Conference on Trade and Development (UNCTAD), as of 17 February 2017, $85^{2}$ BITs have been concluded amongst

8 Economic Commission for Africa and African Union, 'Draft Pan-African Investment Code' (Meeting of the Committee of Experts, Addis Ababa, 31 March-2 April 2016) UN Docs E/ ECA/COE/35/18, AU/STC/FMEPI/EXP/18(II). On the document, see Makane Mbengue, 'The Quest for a Pan-African Investment Code to Promote Sustainable Development' (2016) 5(5) Bridges Africa 4 <www.ictsd.org/sites/default/files/review/BA_June.pdf> accessed 17 February 2017. See also Makane Mbengue and Stefanie Schacherer, 'The 'Africanization' of International Investment Law: The Pan-African Investment Code and the Reform of the International Investment Regime' (2017) 18 JWIT 449 (in this Special Issue).

9 Unless otherwise indicated, the text of the treaties referred to in the article are available at UNCTAD, 'International Investment Agreements Navigator' < http://investmentpolicyhub .unctad.org/IIA > accessed 27 February 2017. 
African States or between them and third States..$^{10}$ Only 496 of them (or $58.21 \%)$, however, are currently in force. The network is clearly underdeveloped as these treaties correspond roughly to $5.54 \%$ of the treaty network necessary to cover all bilateral relationships amongst African States and between them and the rest of the world. ${ }^{11}$ Furthermore, the number of BITs concluded by African countries varies remarkably. Suffice it to mention that the aggregate number of BITs applicable to Algeria, Egypt, Libya, Morocco and Tunisia amounts to 202 (out of 301 signed), or the equivalent of $40.72 \%$ of the BITs in force in the entire continent.

In addition to the irregular distribution of BITs in force and the extremely high percentage of unratified BITs, which seems to be a striking peculiarity of BITs concluded by and amongst African States, two more elements emerge from the recent practice. First, BITs are increasingly less popular amongst African States. African States negotiate and conclude BITs at a significantly slower rate compared to the record figures recorded in the 199os. Indeed, since January 2014 only 27 BITs (including five between African countries) have been signed and only seven of them (including two between African countries) have entered into force. At the same time, several BITs have been terminated or not been renewed. South Africa alone had put an end to thirteen BITs in combination with the adoption of a domestic piece of legislation on the protection of investment. $^{12}$

10 ibid. See also Francesco Seatzu and Paolo Vargiu, 'Africanizing Bilateral Investment Treaties ('BITs'): Some Case Studies and Future Prospects of a Pro-Active African Approach to International Investment' (2015) 30 Conn JIL 143.

11 To cover the totality of bilateral relationships between the 54 African States it is necessary to conclude a number of bilateral treaties equivalent to: $54 \times(54-1) / 2$ or 1,431 BITs. See Émile Giraud, 'Modification et terminaison des traités collectifs' (1961) 49 Annuaire de l'Institut de droit international 1, 16 et seq. To cover the bilateral relationships between the 54 African States and the remaining States, using the 193 current UN membership as the benchmark, it is necessary to conclude $54 \times\left(193^{-54}\right)=7,506$ BITs. The grand total is 8,937 BITs.

12 See Xavier Carim, 'Lessons from South Africa's BITs Review' Columbia FDI Perspectives No 109 (2013) <http://ccsi.columbia.edu/files/2013/10/No_109_-_Carim_-_FINAL.pdf>; Jackwell Feris, 'Challenging the Status Quo - South Africa's Termination of Its Bilateral Trade Agreements' (10 December 2014) <www.dlapiper.com/en/europe/insights/ publications/2014/12/international-arbitration-newsletter-q4-2014/challenging-the -status-quo>; Engela C Schlemmer, 'An Overview of South Africa's Bilateral Investment Treaties and Investment Policy' (2016) 31 ICSID Review 167. The South African Investment Act 2015 is available at <www.thedti.gov.za/gazzettes/39514.pdf > all accessed 17 February 2017. For a preliminary analysis, see Tarcisio Gazzini, 'Travelling the Domestic Route: The South African Investment Act 2015' (2017) 25 African JICL (forthcoming). 
Second, BITs concluded by African States with non-African States are increasingly more balanced and sophisticated. The BIT between Japan and Mozambique, ${ }^{13}$ for instance, contains alongside the common standards on the promotion and protection of foreign investment, provisions on transparency (Article 8), public participation in the adoption, amendment and repeal of related regulations (Article 9), measures against corruption (Article 10), general and security exceptions (Article 18), temporary safeguard measures (Article 19), prudential measures (Article 20), and health, safety and environmental measures and labour standards (Article 24).

BITs concluded between Africa countries, on the contrary, still tend to adhere to the traditional model, which is essentially economic-oriented and often manifestly unbalanced in favour of foreign investors. Some encouraging signs of a more balanced and more inclusive approach can be detected in some recent BITs, such as in Article 11 of the BIT between Congo and Mauritius on the measures necessary to protect public health, ${ }^{14}$ or the Preamble of the BIT between Egypt and Mauritius. ${ }^{15}$

\subsubsection{Facilitation Agreements}

In 2015, Brazil concluded facilitation agreements with Angola, Mozambique and Malawi. ${ }^{16}$ These agreements aim at facilitating and fostering reciprocal

13 Agreement between the Government of Japan and the Government of the Republic of Mozambique on the Reciprocal Liberalisation, Promotion and Protection of Investment (signed 2 June 2013, entered into force 29 August 2014). The BITs concluded by Canada with some African States adopt similar, more balanced approaches. See, for instance, the BITs concluded with Benin (2013), Cote d'Ivoire (2014), Mali (2014), Senegal (2014) and Tanzania (2013). A similar approach is taken by the Treaty between the Government of the United States of America and the Government of the Republic of Rwanda Concerning the Encouragement and Reciprocal Protection of Investment (signed 19 February 2008, entered into force 1 January 2012).

14 Accord entre le gouvernement de la République du Congo et le gouvernement de la République de Maurice sur l'encouragement et la protection réciproque des investissements (signed 20 December 2010, entered into force 15 December 2013).

15 Agreement between the Government of the Republic of Mauritius and the Government of the Arab Republic of Egypt on the Reciprocal Promotion and Protection of Investments (signed 25 June 2014, entered into force 17 October 2014).

16 See the presentation by the Brazilian Ministry of Development, Industry and External Trade, 'Cooperation and Facilitation Investment Agreement - CFIA' < http://unctad-world investmentforum.org/wp-content/uploads/2015/o3/Brazil_side-event-Wednesday _model-agreements.pdf $>$. See also the agreement between Brazil and Mozambique, Acordo Brasil-Moçambique de Cooperação e Facilitação de Investimentos (ACFI) (signed 30 March 2015, not yet in force) <www.itamaraty.gov.br/index.\%2ophp?option=com 
investments 'through the establishment of thematic agendas for cooperation and investment facilitation and through the development of mechanisms for risk mitigation and conflict prevention, among other mutually agreed upon instruments. ${ }^{17}$ Firmly anchored in domestic law, these agreements significantly downgrade the protection of foreign investment normally ensured in BITs as they do not contain any provision on fair and equitable treatment and do not provide for investor-State arbitration.

\subsubsection{Bilateral Trade and Investment Framework Agreements (TIFAs)}

The United States have concluded Trade and Investment Framework Agreements (TIFAs) with several African States. Currently, six TIFAs are in force, namely with Liberia, Mauritius, Rwanda, Mozambique, Nigeria and South Africa. ${ }^{18}$ TIFAs exist normally, but not necessarily in the absence of a BIT (the US has BITs currently in force with Rwanda ${ }^{19}$ and Mozambique ${ }^{20}$ ). These agreements, which cover both trade and foreign investment, are essentially hortatory in character; they do not include any specific standard of protection or any mechanism for the settlement of disputes. Instead, they establish joint trade and investment councils with consultative powers. Similar agreements called 'Agreements concerning the development of trade and investment relations' - had been concluded in the past by the United States with Egypt and Ghana. ${ }^{21}$

_content\&view $=$ article\&id $=8511 \&$ catid $=42 \&$ Itemid $=280 \&$ lang $=p t-B R>$. In literature, see Nitish Monebhurrun, 'Novelty in International Investment Law: The Brazilian Agreement on Cooperation and Facilitation of Investments as a Different International Investment Agreement Model' (2017) 8(1) JIDS 79; Fabio Morosini and Michelle Ratton Sanchez Badin, 'The Brazilian Agreement on Cooperation and Facilitation of Investments (ACFI): A New Formula for International Investment Agreements?' (2015) 6(3) Investment Treaty News 3 <www.iisd.org/sites/default/files/publications/iisd-itn-august-2015-english.pdf> all accessed 17 February 2017 .

17 See Brazil-Mozambique ACFI (n 16) art 3.

18 For more details on the US TIFAs with African States see UNCTAD 'International Investment Agreements Navigator' <http://investmentpolicyhub.unctad.org/IIA/Countr yOtherIias/223\#iiaInnerMenu $>$ accessed 27 February 2017.

19 US-Rwanda BIT (n 13).

20 Treaty between the Government of the United States of America and the Government of Mozambique Concerning the Encouragement and Reciprocal Protection of Investment (signed 1 December 1998, entered into force 3 March 2005).

21 Agreement between the Government of the Arab Republic of Egypt and the United States of America Concerning the Development of Trade and Investment Relations (signed 1 July 1999, entered into force 1 July 1999); Agreement between the Government of the 
2.1.4 Free Trade Agreements

A few FTAs have been concluded between African States and third States. The FTA between the United States and Morocco ${ }^{22}$ remains quite unique insofar as it contains a chapter on investment the substantive and procedural provisions of which are comparable to those typically contained in BITs. Other FTAs concluded between Turkey and three African States (Morocco, ${ }^{23}$ Egypt $^{24}$ and Tunisia ${ }^{25}$ ), on the contrary, do not contain a specific chapter on investment, but only certain provisions on matters related to investment.

\subsection{Multilateral Agreements}

2.2.1 Regional Agreements on the Promotion and Protection of Foreign Investment

Several African regional organizations have concluded agreements or other legal instruments for the promotion and protection of foreign investment between their members. Their experiences vary significantly, but undoubtedly demonstrate great dynamism. As will be seen later, these instruments contain numerous innovative provisions meant to strike a better balance between the rights, interests and expectations of the different stakeholders.

The most sophisticated and important legal instruments dealing with the promotion and protection of foreign investment are the Southern African Development Community (SADC) Protocol on Finance and Investment (Annex 1: Co-operation on investment), ${ }^{26}$ the Economic Community of West

Republic of Ghana and the United States of America Concerning the Development of Trade and Investment Relations (signed 1 July 1999, entered into force 1 July 1999).

22 Free Trade Agreement between the Kingdom of Morocco and the United States of America (signed 15 June 2004, entered into force 1 January 2006). For the sake of simplicity, in this article the expression Free Trade Agreement (FTA) is used interchangeably with Regional Economic Community (REC) and Regional Trade Agreement (RTA).

23 Free Trade Agreement between the Kingdom of Morocco and the Republic of Turkey (signed 7 April 2004, entered into force 1 July 2005).

24 Agreement Establishing a Free Trade Area between the Arab Republic of Egypt and the Republic of Turkey (signed 27 December 2005, entered into force 1 March 2007).

25 The Association Agreement Establishing a Free Trade Area between the Republic of Turkey and the Republic of Tunisia (signed 25 November 2004, entered into force 1 July 2005).

26 Southern African Development Community (SADC) Protocol on Finance and Investment (concluded 18 August 2006, entered into force 16 April 2010) <www.sadc.int/ files/4213/5332/6872/Protocol_on_Finance_Investment20o6.pdf > accessed 17 February 2017. It has been reported that in August 2016 the Member States of SADC agreed on important amendments to the Protocol, most prominently the removal of the fair and equitable treatment provision and the exclusion of investor-State international 
African States (ECOWAS) Supplementary Act adopting Community Rules on Investment and the Modalities for Their Implementation with ECOWAS, ${ }^{27}$ and the Investment Agreement for the Common Market for Eastern and Southern Africa (COMESA) Common Investment Area. ${ }^{28}$

Legal instruments concluded within other regional organisations contain less detailed and less systematic compilation of substantive and procedural provisions on investment. They include the East African Community (EAC) Model Investment Code, ${ }^{29}$ the Community Investment Code of the Economic Community of the Great Lakes Countries (in French, Communauté Economique des Pays des Grands Lacs - CEPGL), ${ }^{30}$ the Arab Maghreb Union Investment Agreement, ${ }^{31}$ and the Common Convention in Investments in the States of the Customs and Economic Union of Central Africa (CEUCA). ${ }^{32}$

arbitration, see Luke Eric Peterson, 'Investigation: In Aftermath of Investor Arbitration Against Lesotho, SADC Member States Amend Investment Treaty so as to Remove ISDS and Limit Protections' (IAReporter, 20 February 2017) <www.iareporter.com/articles/ investigation-in-aftermath-of-investor-arbitration-against-lesotho-sadc-member-states -amend-investment-treaty-so-as-to-remove-isds-and-limit-protections/> accessed $\quad 27$ February 2017.

27 ECOWAS, Supplementary Act A/SA.3/12/08 Adopting Community Rules on Investment and the Modalities for their Implementation with ECOWAS (adopted 19 December 2008, entered into force 19 January 2009) <http://investmentpolicyhub.unctad.org/Download/ TreatyFile/3266> accessed 17 February 2017. It is annexed to the ECOWAS Treaty of which it constitutes an integral part (art $42(2))$.

28 Investment Agreement for the COMESA Common Investment Area (adopted 23 May 2007, not yet in force) <http://investmentpolicyhub.unctad.org/Download/TreatyFile/ 3092> accessed 17 February 2017.

29 East African Community Model Investment Code (2006) <www.tralac.org/images/ Resources/EAC/EAC\%2oModel\%2oInvestment\%20Code\%2020o6.pdf> accessed 17 February 2017. According to art 3(1), "[t]he provisions of this Code may be adopted into investment policies or enacted in the investment laws of a Partner State and to that extent this Code shall remain a guiding instrument without any binding effect on any Partner State'.

30 Community Investment Code of the Economic Community of the Great Lakes Countries (CEPGL) (adopted 31 January 1982, entered into force 4 October 1987) <http://investment policyhub.unctad.org/Download/TreatyFile/2400> accessed 17 February 2017.

31 Agreement on Protection and Promotion of Investments between Algeria, Tunisia, Morocco, Mauritania and Libya (adopted 23 July 1990, not yet in force) < http://investment policyhub.unctad.org/Download/TreatyFile/2405> accessed 17 February 2017.

32 Common Convention on Investments in the States of the Customs and Economic Union of Central Africa (adopted 14 December 1965, entered into force 1 April 1966) <http:// investmentpolicyhub.unctad.org/Download/TreatyFile/2388> accessed 17 February 2017. 
Finally, other regional organizations whose membership includes several African States have concluded investment treaties. This is the case, most prominently, of the Investment Agreement concluded within the Organisation of Islamic Cooperation (formerly Organization of the Islamic Conference) (OIC), ${ }^{33}$ and the Agreement on Investment and Free Movement of Arab Capital among Arab Countries concluded within the Arab League. ${ }^{34}$

\subsubsection{Economic Partnership Agreements Between African Regional Organisations and the European Union}

Another important development in the investment agreements landscape is the negotiation and conclusion of Economic Partnership Agreements (EPAs) between African regional organizations and the European Union (EU). ${ }^{35}$ One such agreement was concluded with ECOWAS on 30 June 2014 (endorsed on 10 July 2014 by ECOWAS Heads of States). ${ }^{36}$ With the signature still pending, Côte d'Ivoire and Ghana completed the ratification process before their respective legislative bodies, thus paving the way to the provisional application of the treaty. The agreement is essentially about trade, but includes several provisions relevant for the promotion and protection of foreign investment as well as a rendez-vous provision expressing the intention of the parties to enter discussion in the area of investment. ${ }^{37}$

33 Agreement on Promotion, Protection and Guarantee of Investments Among Member States of the Organisation of the Islamic Conference (adopted 5 June 1981, entered into force 23 September 1986) <http://investmentpolicyhub.unctad.org/Download/Treaty File/2399> accessed 17 February 2017.

34 Agreement on Investment and Free Movement of Arab Capital Among Arab Countries (signed and entered into force 29 August 1970) <http://investmentpolicyhub.unctad.org/ Download/TreatyFile/2390 $>$ accessed 17 February 2017.

35 For an overview of EPAs and current status see European Commission, 'Overview of Economic Partnership Agreements (January 2017) <http://trade.ec.europa.eu/doclib/ docs/2009/september/tradoc_144912.pdf > accessed 17 February 2017.

36 European Commission, 'West African Leaders Back Economic Partnership Agreement with EU' (11 July 2014) <http://europa.eu/rapid/press-release_IP-14-827_en.htm> accessed 17 February 2017. See, in general, Paul Kuruk, 'Investment Issues in the West Africa-European Union Economic Partnership Agreement Negotiations: Is a Harmonised Regional Investment Framework the Answer?' (2012) 20(3) African JICL 448.

37 Economic Partnership Agreement between the West African States, the Economic Community of West African States (ECOWAS) and the West African Economic and Monetary Union (UEMOA) and the European Union and its Member States (final text) (2014) art 106(1)(e) <http://trade.ec.europa.eu/doclib/docs/2015/october/tradoc_153867 .pdf> accessed 17 February 2017. 
Another EPA has been concluded on 15 July 2014 between the EU and SADC after ten years of negotiations. ${ }^{38}$ The agreement will replace the interim agreement concluded in 2009 - which never entered into force - between the European Communities and its Members, on the one side, and some SADC members (namely Botswana, Lesotho, Mozambique, Namibia and Swaziland) on the other side. ${ }^{39}$ The agreement provisionally applies since 10 October 2014 pending the ratification. The new agreement must be welcome since SADC members were able to overcome their divisions and deal with the EU as a single block, presumably with enhanced bargaining power and for the mutual benefit of all parties in terms of normative efficiency and predictability as well as of economic advantages and competitiveness. ${ }^{40}$

On other occasions, negotiations intended to involve regional organizations were less productive. This was the case of the negotiations between the EU and the Central African States, which eventually resulted only in an interim EPA with Cameroon on 15 January 2009, which has been provisionally applied since 4 August 2014. ${ }^{41}$

The EU has also concluded, with a couple of North African States, association agreements, which include a broad provision on the promotion and protection of investment. ${ }^{42}$ With a view to upgrade these agreements, on

38 Economic Partnership Agreement between the European Union and Its Member States and the SADC EPA States (signed 10 June 2016, not yet in force) [2016] OJ L250/3.

39 Interim Agreement with a View to an Economic Partnership Agreement between the European Community and Its Member States and the SADC EPA States (adopted 22 January 2009, not in force) <http://ec.europa.eu/world/agreements/downloadFile .do?fullText=yes\&treatyTransId=13464> accessed 17 February 2017.

40 It is worth noting that a similar unsatisfactory outcome resulted from the negotiation of an EPA between the EU, COMESA and their respective members. The agreement was concluded by only six member of the latter organization (Comoros, Madagascar, Mauritius, Seychelles, Zambia and Zimbabwe). The agreement is provisionally applied since 14 May 2012.

41 Interim Agreement with a View to an Economic Partnership Agreement between the European Community and Its Member States, of the One Part, and Cameroon, of the Other Part [2009] OJ L57/1.

42 See, for instance, Article 50 of the Association Agreement with Morocco, concluded on 26 February 1996 and entered into force on 1 March 2000, <http://eur-lex.europa.eu/ legal-content/EN/TXT/?uri=uriserv:OJ.L_.2000.070.01.0002.01.ENG\&toc=OJ:L:2000:070: TOC > accessed 26 February 2017, which reads: 'The aim of cooperation shall be to create a favourable climate for flows of investment, and to use the following in particular: (a) the establishment of harmonised and simplified procedures, co-investment machinery (especially to link small and medium-sized enterprises) and methods of identifying and providing information on investment opportunities; (b) the establishment, where 
14 December 2011, the Council adopted negotiating directives for the conclusion of Deep and Comprehensive Free Trade Agreement (DCFTA), which are expected to include a chapter on the promotion and protection of foreign investment, and gave the mandate to the European Commission to start the negotiating process. ${ }^{43}$ Negotiations are currently underway between the EU and Morocco, Tunisia, ${ }^{44}$ and Egypt.

\subsubsection{Framework Agreements Between African Regional Organisations and the United States}

The United States has concluded framework agreements with a couple of African regional organizations, such as with COMESA, ${ }^{45}$ EAC, ${ }^{46}$ Southern African Customs Union (SACU) ${ }^{47}$ and ECOWAS. ${ }^{48}$ Similar to TIFAs, these

appropriate, of a legal framework to promote investment, chiefly through the conclusion by Morocco and the Member States of investment protection agreements and agreements preventing double taxation'. Similar agreements have been concluded with Tunisia, Egypt and Algeria.

43 European Commission, 'EU Agrees to Start Trade Negotiations with Egypt, Jordan, Morocco and Tunisia', News Archive <http://trade.ec.europa.eu/doclib/press/index .cfm?id=766> accessed 26 February 2017.

44 See also the texts proposed by the EU for a Deep and Comprehensive Free Trade Area (DCFTA) with Tunisia, 26 April $2016<$ http://trade.ec.europa.eu/doclib/press/index.cfm ?id=1490 $>$ accessed 26 February 2017. See also World Bank, 'Advancing Tunisia's Global Integration: Reforms Options in the Context of Deeper Integration with the EU' vol I (Main Report) (2014) <http://documents.worldbank.org/curated/en/2014/06/19799817/ tunisia-advancing-tunisias-global-integration-reforms-options-context-deeper -integration-eu-vol-1-2-main-report> accessed 17 February 2017.

45 Agreement between the Common Market For Eastern And Southern Africa (COMESA) and the United States of America Concerning the Development of Trade and Investment Relations (COMESA-US TIFA) (signed 29 October 2001, entered into force 29 October 2001) <http://investmentpolicyhub.unctad.org/Download/TreatyFile/2516> accessed 27 February 2017.

46 Trade and Investment Framework Agreement between the United States and the East African Community (EAC-US TIFA) (signed 16 July 2008, entered 16 July 2008) <http:// investmentpolicyhub.unctad.org/Download/TreatyFile/2556> accessed 27 February 2017.

47 Cooperative Agreement between the United States of America and the Southern African Customs Union to Foster Trade, Investment and Development (SACU-US TIFA) (signed 16 July 2008, entered into force 16 July 2008) <http://investmentpolicyhub.unctad.org/ Download/TreatyFile/2555 > accessed 27 February 2017.

48 Trade and Investment Framework Agreement between the Government of the United States of America and the Economic Community of West African States (signed 5 August 2014, not yet in force) <http://investmentpolicyhub.unctad.org/Download/ TreatyFile/5102> accessed 27 February. 
agreements are largely hortatory and impose only loose obligations upon the parties, primarily with regard to the establishment of consultative joint councils.

\subsubsection{Sector Agreements (Energy ECOWAS)}

In 2003, ECOWAS members concluded an Energy Protocol deliberately inspired by the Energy Charter Treaty (ECT),${ }^{49}$ which is described in the preamble as the 'leading internationally accepted basis for the promotion, cooperation, integration and development of energy investment projects and energy trade among sovereign nations' ${ }^{50}$ Many of the substantive provisions contained in the Protocol reproduce or mirror those of the ECT.

\section{From Globalism and Bilateralism Towards Regionalism}

Keeping in mind the complex legal framework sketched in the previous Part and before delving into the contribution of African regional organizations to the development of the promotion and protection of foreign investment, it is worth discussing the rise and evolution of economic regional integration, with a special focus on Africa. To contextualise the discussion and appreciate the progressive development in Africa of regional investment treaties also in relation to the progressive development of legal instruments on trade relations, it must be recalled that the contemporary regulatory system of the global economy has been shaped in three different spaces, each furnished with distinct institutions and legal frameworks. The distinct regimes on trade, investment and monetary affairs do not always appear to be dictated by well-considered choices, but rather by incongruity of expertise. Monetary specialists, trade

49 Energy Charter Treaty (signed 17 December 1994, entered into force 16 April 1998), <www .encharter.org/fileadmin/user_upload/document/EN.pdf> accessed 17 February 2017.

$5^{0}$ ECOWAS Energy Protocol A/P4/1/03 (adopted 31 January 2003, not yet in force) <http:// investmentpolicyhub.unctad.org/Download/TreatyFile/2525> accessed 17 February 2017. See also Matteo Barra and Tomasz Bąk, 'Mobilising Sustainable Energy Investments in Africa: The Role of the International Energy Charter' (September 2016) <www.energy charter.org/fileadmin/DocumentsMedia/Other_Publications/20160915-Mobilising _Sustainable_Energy_Investments_in_Africa.pdf> accessed 17 February 2017; the Protocol on Energy in the Southern African Development Community (SADC) Region (concluded 24 August 1996) <www.sadc.int/files/3913/5292/8363/Protocol_on_Energy1996.pdf> accessed 24 April 2017, and the COMESA Model Energy Policy Framework (concluded April 2008) <www.comesa.int/wp-content/uploads/2016/12/COMESA-MODEL-ENERGYPOLICY-FRAMEWORK-EN-1.pdf $>$ accessed 24 April 2017. 
diplomats and investment lawyers each have often tended to live in their own confinement creating their own idiom and interpretations. ${ }^{51}$

The distinctive development of legal regimes was not evident in the 1948 Havana Charter, drafted to establish the International Trade Organization (ITO). In addition to an extensive trade agenda, the ITO was authorized to 'formulate and promote the adoption of a general agreement or statement of principles regarding the conduct, practices and treatment of foreign investment. ${ }^{52}$ The Havana Charter also called on member States to provide reasonable opportunities for investments acceptable to them and adequate security for existing and future investments, and to give due regard to the desirability of avoiding discrimination as between foreign investments. ${ }^{53}$ The Charter 'faded away' after the US government declined to submit the agreement for approval to Congress. The General Agreement on Tariffs and Trade (GATT), as a leftover, survived as an instrument for trade liberalization. ${ }^{54} \mathrm{~A}$ different outcome might have resulted in a multilateral and probably more balanced approach towards the trade and investment agenda. This approach has currently been embraced in regional trade and investment agreements. In the Preamble of the SADC Protocol on Finance and Investment, ${ }^{55}$ for instance, the parties recognized 'the importance of the link between investment and trade, and the need for greater regional cooperation to enhance the attractiveness of the Region as an investment destination. ${ }^{56}$

$5^{1}$ Accordingly, the requirement of 'fair and equitable treatment', a well-developed concept in investment law, is not matched by similar treatment of international traders. Likewise, the regulatory framework of subsidies in WTO law is not matched by a similar commitment in international investment law. Yet, it is unclear why a subsidized investor is a lesser threat for fairness in competition than a subsidized trader.

$5^{2}$ Havana Charter for an International Trade Organization (adopted 24 March 1948) $\operatorname{art} 11(2)$ (c) <www.wto.org/english/docs_e/legal_e/havana_e.pdf>.

53 ibid art 12(2)(a).

54 John H Jackson, Sovereignty, the WTO and Changing Fundamentals of International Law (CUP 2006) 94. Andreas Lowenfeld, International Economic Law (2nd edn, OUP 2002) 26. The same author notes that the failure of the ITO was unrelated to investment issues (ibid 405).

55 See SADC Protocol (n 27).

56 See, for instance, art $3(\mathrm{f})$ of the Interim Agreement between the European Community and Cameroon (n 41), indicates amongst its general objective the establishment and implementation of 'an effective, predictable and transparent regulatory framework for trade and investment in the Central African region, thus supporting the conditions for increasing investment and private-sector initiatives, and enhance capacity for the supply of products and services, competitiveness and economic growth in the region'. Likewise, the Preamble of the Tripartite Free Trade Area Agreement, recognizes that 'the development of trade and investment is essential to the economic integration of the region and 
From the adoption of the GATT in 1947 and the establishment of the World Trade Organization (WTO) in 1995, the world trading system has developed into a comprehensive set of agreements and understandings. Uniformity was secured by the principle of 'single undertaking', meaning that each adopted text is part of a whole and indivisible package and cannot be agreed separately. In other words, nothing is agreed until everything is agreed. As a result, all WTO Members ${ }^{57}$ are bound by identical texts without having the opportunity for individual members to opt out parts of the agreements. Critics argue that it is an illusion to think that Members with considerable diversity in their economic needs and bureaucratic capacity can ever agree on complex new provisions all at once. ${ }^{58}$ The so-called 'Single Undertaking' not only slows down multilateral liberalization but may even hamper any progress towards further liberalisation. ${ }^{59}$

In sharp contrast with the development of a uniform global trade framework, investment law has followed a completely different path, which has led to a complex network of treaties composed essentially of 2,329 BITs and 297 treaties with investment provisions (TIPs, using UNCTAD terminology) currently in force. ${ }^{60}$ Undoubtedly, bilateralism offers clear advantages by creating maximum flexibility to tailor to the special needs of each couple of States. ${ }^{61}$ This applies not only to the negotiation and conclusion of these treaties, but also to the adoption of the amendments that may be necessary to upgrade them in order to match the continuing evolution of the international legal order (especially as far as the protection of the environment, human and social rights are concerned).

will create new opportunities for a dynamic business sector', Agreement Establishing the COMESA, EAC and SADC Tripartite Free Trade Area (signed 10 June 2015, not yet in force) < www.tralac.org/images/docs/7646/signed-tfta-agreement-and-declaration-june -2015.pdf $>$ accessed 17 February 2017.

57 In July 2016 the WTO counted 164 members, covering $97 \%$ of the world trade.

$5^{8}$ Claus-Dieter Ehlermann and Lothar Ehring, 'Decision-Making in the World Trade Organisation: Is the Consensus Practice of the World Trade Organisation Adequate for Making, Revising and Implementing Rules on International Trade' (2005) 8 JIEL 51.

59 Robert Wolfe, 'The WTO Single Undertaking as Negotiating Technique and Constitutive Metaphor' (2009) 12(4) JIEL 835.

6 o UNCTAD (n 4).

61 As noted by Kevin C Kennedy, 'A WTO Agreement on Investments: A Solution in Search of a Problem' (2003) 24 U Pa J Intl Econ L 77, 183 (stating that '[b]ilateral investment agreements offer the flexibility that is not possible under a multilateral framework. BITs can be tailored to fit country-specific needs in a way that is not possible under a multilateral framework'). See also UNCTAD, International Investment Agreements: Flexibility for Development (United Nations 2000). 
In an attempt to create order in the multitude of bilateral agreements, a multilateral treaty on investment was proposed both within the inner circle of developed States ${ }^{62}$ and in the broader environment of the WTO. ${ }^{63}$ However, the conclusion of a multilateral framework seems to be today ever more remote than in the past, inter alia, because of the increasing divergences between model BITs. As a result, States seem to be bound to live, at least in the near future, with the prevalent current bilateral legal framework and its undeniable complexity and shortcomings, which are often amplified by the inadequate level of consistency and predictability that unavoidably characterize current investment disputes. ${ }^{64}$

A combination of inflexibility of legal regimes and insurmountable opposing views between the developing and developed world has contributed to the discontents of the world trade and investment regime that has surfaced in recent years. The WTO is today perceived as being increasingly incapable to respond to a rapidly changing world. ${ }^{65}$ Various groups of WTO Members have different interests and are unwilling to trade off concessions and benefits. In the WTO Doha Round, negotiations a number of issues were suspended

62 See OECD, 'Multilateral Agreement on Investment Draft Consolidated Text and Commentary' (22 April 1998), respectively Docs DAFFE/MAI(98) 7 /REVI and DAFFE/ MAI(98)8/REVI. See also UNCTAD, Lessons from the MAI (United Nations 1999); Peter Muchlinski, 'The Rise and Fall of the Multilateral Agreement on Investment: Where Now?' (2000) 34 Intl Lawyer 1033.

63 See WTO, 'Doha Work Programme: Decision Adopted by the General Council on 1 August 2004' (2 August 2004) WT/L/579.

64 See Gus Van Harten, Investment Treaty Arbitration and Public Law (OUP 2007); Michael Waibel and others (eds), The Backlash against Investment Arbitration (Kluwer 2010); Gus Van Harten, 'Five Justifications for Investment Treaties: A Critical Discussion' (2010) 2 Trade, Law \& Development 1; Stephan W Schill and Mark Jacob, 'Common Structures of Investment Law in an Age of Increasingly Complex Treaty-Making' Columbia FDI Perspectives No 94 (2013) <http://ccsi.columbia.edu/files/2014/o1/FDI_94.pdf> accessed ${ }_{17}$ February 2017. For a critical look at the BIT between China and African States, see Uche Ewelukwa Ofodile, 'Africa-China Bilateral Investment Treaties: A Critique' (2013) 35 Mich J Intl L 131 .

65 See, eg, the remark made by Pascal Lamy, Director-General of the WTO, 2005-2013, at an informal heads of delegation meeting of the Trade Negotiating Committee on 26 July 2011: 'What we are seeing today is the paralysis in the negotiating function of the WTO, whether it is on market access or on the rule-making. What we are facing is the inability of the WTO to adapt and adjust to emerging global trade priorities, those you cannot solve through bilateral deals' <www.wto.org/english/news_e/newsil_e/tnc _infstat_26jul11_e.htm> accessed 17 February 2017. 
and some items (investment and competition) have been removed from the negotiating agenda. Remnant negotiations have been stalled by considerable disagreement on agricultural trade reforms. The adoption of the WTO Trade Facilitation Agreement ${ }^{66}$ could hardly conceal the deeply rooted problems that prevent the world trading system from keeping vibrant. ${ }^{67}$ Moreover, increasing criticism is mounted against international investment agreements and particularly the arbitration clauses incorporated therein. ${ }^{68}$ Investor's claims based on such clauses are perceived as threatening the regulatory autonomy of host States. Recent years a number of developing countries have tried to escape from the arbitration system by denouncing the investment treaties to which they are party. These attempts were frequently unsuccessful. ${ }^{69}$

Against this general background, new modalities of economic cooperation have evolved at the regional level. Regional economic cooperation creates considerable advantages that are not available under the multilateral trading system. Countries are not restricted by the limitations on global cooperation as stipulated by the WTO institutional framework. Accordingly, items that are not on the WTO agenda, such as labour mobility, investment, competition, government procurement, environmental protection and monetary arrangements, may be negotiated and included in the relevant legal documents of FTAs. Moreover, regionalism does not force parties to extend mostfavoured nation (MFN) treatment to unwelcome trading partners and creates

66 WTO members adopted at the 2013 Bali Ministerial Conference the Trade Facilitation Agreement (TFA), which entered into force on 22 February 2017. The TFA facilitates the movement, release and clearance of goods, including goods in transit. In addition, it provides for effective cooperation between customs and other appropriate authorities on trade facilitation and customs compliance issues. Text and commentary available at <www.wto.org/english/tratop_e/tradfa_e/tradfa_e.htm> accessed 26 February 2017.

67 David Kleimann and Joe Guinan, 'The Doha Round: An Obituary' Global Governance Programme Policy Brief No 2011/1 (European University Institute 2011) $1<$ http://global governanceprogramme.eui.eu/wp-content/themes/NewEuitemplate/Documents/ Publications/PolicyBriefs/PolicyBrief20111final.pdf > accessed 17 February 2017.

68 For an overview, see Laurens Ankersmit, 'Investment Court System in CETA to Be Judged by the ECJ' <http://europeanlawblog.eu/2016/10/31/investment-court-system-in-ceta-to -be-judged-by-the-ecj> accessed 26 February 2017. See also objection from Belgium against CETA's clauses on investment arbitration <www.euractiv.com/section/trade -society/opinion/wallonias-stand-on-ceta-is-good-for-europe-and-the-world/> accessed 26 February 2017.

69 Federico Lavopa, Lucas E Barreiros, M Victoria Bruno, 'How to Kill a BIT and Not Die Trying: Legal and Political Challenges of Denouncing or Renegotiating Bilateral Investment Treaties' (2013) 16 JIEL 869. 
opportunities for advanced liberalization beyond what would be feasible under the WTO system.

Another important advantage of regionalism is the opportunity to merge trade and investment disciplines into a single legal framework. This development responds to the need of commerce where value chains feature prominently. Goods are being processed - and value being added - in multiple countries that are part of the chain. ${ }^{70}$ Regional FTAs are an institutional response to the needs of value chain markets.

If economic factors driving States towards the establishment of FTAs, including enhanced efficiency and competiveness, improved access to markets and reduction of transaction costs, are evident, political considerations should not be neglected. ${ }^{71}$ Firstly, regionalism is a self-generating process creating more regionalism; countries that are left out of a regional arrangement tend either to join at a later stage or to search for their own FTA in order to escape from the marginalization syndrome. Secondly, regionalism creates security as it brings confidence and improves diplomacy within the region and beyond. Regional cooperation also enables parties to pursue convergence of trade, investment and monetary disciplines in a joint institutional framework and thereby create a market with common objectives, principles and a dispute settlement system that is sensitive to both economic and societal interests of that region. In addition, regional cooperation facilitates joined economic representation on the global arena where economically small or weak States have little negotiating power.

The advantages mentioned here do not necessarily mean that regionalism conflicts with trade disciplines as conceived by the WTO. Rather regionalism may be considered as complementary to the world trading system. The Organisation for Economic Co-operation and Development (OECD) discerns converging and diverging effects of FTAs on the world trading system. ${ }^{72}$ FTAs may have a harmonizing effect by drawing on or replicating underlying WTO approaches or by helping to forge model approaches, possibly even for subsequent adoption in a WTO setting. In that sense, FTAs help to make advanced rules and reverse the fear that international agreements cause a race to the

70 See UNCTAD, World Investment Report 2013. Global Value Chains and Development: Investment and Added Value Trade in the Global Economy (United Nations 2013).

71 Chad Damro, 'The Political Economy of Regional Trade Agreements' in Lorand Bartels and Federico Ortino (eds), Regional Trade Agreements and the WTO Legal System (OUP 2006) 23 .

72 OECD, 'Regionalism and the Multilateral Trading System' (2003) < www.bilaterals.org/ IMG/pdf/OECD_RTAs_book_julo3.pdf> accessed 17 February 2017. 
bottom. Accordingly, FTAs may set advanced technical standards or adopt understandings on societal values. Such standards and understandings may be used as evidence of State practice and be applied, through interpretation, ${ }^{73}$ in the world trading system in terms of social standards. On the other hand, the proliferation of FTAs may also be a source of divergence. FTAs in regions may distort the world trading system by setting deviating rules and standards which undermine the unified disciplines of the world trading system. In case a country has FTA partners, complex import rules apply depending on the origin of the product and this decreases transparency and uniformity. There may also be different rules within a single jurisdiction on dumping, subsidies or safeguard measures, depending whether the product origins from a FTA partner.

Despite concerns about the proliferation of FTAs, they are a valid and effective response to the desire of trading partners to merge trade and investment regimes and to address a broader range of interests, such as the protection of the environment, competition and labour mobility. In various regions, deeper and broader economic integration has been a prime objective of trading partners. The African continent is a conspicuous example of such integration.

\section{$4 \quad$ African Regionalism}

The drive towards African economic integration demonstrates a strong aspiration to promote prosperity across the African continent, albeit not without surmounting considerable obstacles. Across the continent, 54 States cooperate in several FTAs ${ }^{74}$ with varying size, scope and effectiveness. Some African States are also members of regional organizations whose constituency spread

73 State practice as reflected in FTAs may be used as a means of interpretation of the WTO agreements. WTO panels and the Appellate Body frequently refer to art 31(3) of the Vienna Convention on the Law of Treaties. In WTO, Japan-Taxes on Alcoholic Beverages, WT/ DS8/AB/R, WT/DS10/AB/R, WT/DS11/AB/R, Report of the Appellate Body (4 October 1996) para 106, the AB stated that 'subsequent practice' within the meaning of Article 31(3)(b) entails "concordant, common and consistent" sequence of acts or pronouncements which is sufficient to establish a discernible pattern implying the agreement of the parties [to a treaty] regarding its interpretation'.

74 They include the Arab Maghreb Union (AMU), Community of Sahel-Saharan States (CEN-SAD), COMESA, EAC, Economic Community of Central African States (ECCAS), ECOWAS, SADC, SACU, Communauté économique et monétaire de l'Afrique centrale (CEMAC), Common Monetary Area (CMA), Indian Ocean Commission (IOC), International Conference on the Great Lakes Region (ICGLR), the Mano River Union (MRU), West African Economic and Monetary Union (WAEMU), CEPGL, and CEUCA. 
across Africa and Asia, namely the Arab League ${ }^{75}$ and the OIC. ${ }^{76}$ In addition, two monetary unions have adopted single currencies pegged to the Euro. ${ }^{77} \mathrm{The}$ form of African economic cooperation follows a pattern that is different from other continents where expansion takes place by a concentric model. Thus, the incremental expansion of the EU took place by drawing increasing wider circles around the original six members. ${ }^{78}$ The African model, by contrast, shows a multipolar image of FTAs. Each FTA creates a cooperative framework between one group of neighbouring countries; each of these FTAs has its own dynamic in terms of internal trade and investment liberalization. As will be explained below, FTAs are expected to merge into a single African economic union within foreseeable time.

The attraction of African regionalism can be explained by a number of reasons related to cultural and historical ties or political preferences. However, economic motives are likely to be the main reason. 54 African countries harbour relatively small economies with the multiplicity of national borders acting as barriers to intra-African trade. In 2010, 24 African countries had a population of less than 10 million, and 17 of less than 5 million. The gross domestic product (GDP) of 29 countries was less than USD 10 billion, and that of 18 countries less than USD 5 billion. ${ }^{79}$ Regional cooperation is a must rather than an option in order to reach a level of 'economies of scale'. There may also be some political motivations. The African continent may suffer from a 'marginalization syndrome' as it is excluded from trade arrangements that feature

75 See the official website <www.lasportal.org > accessed 19 February 2017. Currently, 10 African States are members of the organization: Algeria, Comoros, Djibouti, Egypt, Libya, Mauritania, Morocco, Somalia, Sudan and Tunisia.

${ }_{76}$ See the official website <www.oic-oci.org/home/?lan=en> accessed 19 February 2017. Currently, 27 African States are members of the organization: Algeria, Benin, Burkina Faso, Cameroon, Chad, Comoros, Cote d'Ivoire, Djibouti, Egypt, Gabon, Gambia, Guinea, Guinea Bissau, Libya, Mali, Mauritania, Morocco, Mozambique, Niger, Nigeria, Senegal, Sierra Leone, Somalia, Sudan, Togo, Tunisia and Uganda.

77 Two monetary zones use a similar common currency. The CFA Franc of the Central Bank of West African States is pegged to the Euro. It is used by Benin, Burkina Faso, Côte d'Ivoire, Guinea-Bissau, Mali, Niger, Senegal and Togo. The CFA Franc of the Bank of Central African States is identically pegged. It is the currency of the Central African States: Cameroon, Central African Republic, Chad, Republic of the Congo, Equatorial Guinea and Gabon.

78 Original members of the European Economic Communities were Belgium, France, the Federal Republic of Germany, Italy, Luxembourg and the Netherlands. The EU now counts 28 Member States. 
in other continents. New arrangements in the making, such as trans-Pacific and trans-Atlantic free trade deals, may easily create the perception that Africa is less relevant in the world trading system.

Another likely reason for the rise of regionalism is the need to increase leverage of African States ${ }^{80}$ and to speak with a single voice when negotiating with other States and the international business community. Thus, by pooling diplomatic resources, developing countries in particular may achieve 'greater prominence in international relations and to negotiate agreements that would not be available if they have acted individually, and to assure election of their representatives to key positions in international organizations. ${ }^{\text {}} 1$

The African map reveals that most FTAs are truly regional in the sense that the States establishing the organizations are adjacent. The traditional distinction between Sahel-Saharan countries and sub Saharan countries does not show in the composition of FTAs. Two large FTAs connect countries throughout the continent: COMESA vertically connects a string of countries from Egypt to Zimbabwe. The Communauté des États Sahélo-sahariens (CEN-SAD) horizontally connects both Arab and sub-Saharan countries from Senegal to Sudan. The legacy of colonialism seems to have little influence on the composition of FTAs although the influence of former colonial powers may have some impact in the formation of FTAs.

African FTAs feature in a long term project of the AU that aims at fully integrating the African continent into a single economic bloc. The 1991 AU Treaty Establishing the African Economic Community (AEC) aims 'to establish, on a continental scale, a framework for the development, mobilisation and utilisation of the human and material resources of Africa in order to achieve a selfreliant development.' 82 Under Article 6 of the Treaty, this ambitious project covers a time span of six stages until its completion in 2028. The plan consists initially in 'strengthening of existing regional economic communities ...' and 'the conclusion of agreements aimed at harmonising and co-ordinating policies among existing and future sub-regional and regional economic

\footnotetext{
$80 \quad$ See on this point Damro (n 71) 34-35.

81 See John Ravenhill, Global Political Economy (4th edn, OUP 2014) 145 (referring to a World Bank study published in 2002).

82 Treaty Establishing the African Community (signed 3 June 1991, entered into force 12 May 1994) art 4(1)(b) <http://investmentpolicyhub.unctad.org/Download/TreatyFile/2406> accessed 17 February 2017. See also Protocol to the Treaty Establishing the African Economic Community Relating to the Pan-African Parliament (adopted 2 March 2001, entered into force 14 December 2003) < www.jus.uio.no/english/services/library/treaties/ 09/9-05/aec_protocoll_panafrican_parlament.xml> accessed 17 February 2017.
} 
communities.83 It then foresees the reduction of tariffs and removal non-tariff barriers. Subsequently, the creation of customs unions, and the harmonization of tariff and non-tariff systems among FTAs will be realized, with a view to establishing a Continental Customs Union. In the final stage, the African Common Market will be established, including an African Economic and Monetary Union and the creation of a Pan-African Parliament. The Treaty also envisages a court that may give advisory opinions and settle disputes. The full economic integration of the African continent is reminiscent to the ambitions realized in Europe. However, there appears a considerable variation in progress made by the various FTAs.

The AU recognizes eight FTAs as constituent elements of the prospective AEC. FTAs are developing at a variable speed and take the shape of free trade areas, customs unions or common markets. The EAC, relatively small in terms of GDP, is considered the most advanced community having launched its customs union in 2010, which is to be followed by a common market. ${ }^{84}$ COMESA has adopted a customs union in June $2009 .{ }^{85}$ ECOWAS and SADC, which are currently established as FTAs, may in due time evolve into customs unions and common markets. ${ }^{86}$ The Economic Community of Central African States (ECCAS) is slightly lagging behind, whereas the Arab Maghreb Union (in French UMA), CEN-SAD and the Intergovernmental Authority on Development (IGAD) show limited levels of activity. ${ }^{87}$

The level of commitment to implement FTAs has been subject to criticism. In its Report on Africa, UNCTAD ${ }^{88}$ criticizes the laxity to remove tariff and non-tariff barriers which has stalled liberalization to a considerable extent.

\footnotetext{
83 ibid art 4(2)(a) and (b).

84 EAC, 'Common Market' <www.eac.int/integration-pillars/common-market> accessed 17 February 2017.

85 COMESA, 'Our Activities: Trade' <www.comesa.int/what-we-do/\#trade-customs -monetary-affairs $>$ accessed 17 February 2017.

86 SADC, 'Free Trade Area' <www.sadc.int/about-sadc/integration-milestones/free-trade -area/>; ECOWAS, 'ECOWAS Trade Liberalization Scheme (ETLS)' <www.etls.ecowas .int $>$ all accessed 17 February 2017.

87 According to African Union Commission, 'Status of Integration in Africa (SIA IV)' (2013) $<$ www.au.int/ar/sites/default/files/SIA\%202013(latest)_En.pdf > accessed 17 February 2017. It is difficult to find updated information about these FTAs. For IGAD see $<$ http:// igad.int $>$ accessed 7 May 2017. For ECCAS see $<$ www.ceeac-eccas.org $>$ accessed 7 May 2017. The UMA website <www.maghrebarabe.org/en> accessed 7 May 2017 is not regularly maintained. CEN-SAD does not publish plans or reports; its website is offline.

88 UNCTAD, Economic Development in Africa Report 2013. Intra African Trade: Unlocking Private Sector Dynamism (United Nations 2013) 58.
} 
The Report addresses inadequate domestic financial resources and dependence on donor funding. The adoption of unrealistic targets and deadlines, and policies to compensate potential losers from integration are some of the reasons for the failure to implement economic cooperation agreements. Often African governments set ambitious targets in action plans, even if they realize that the deadlines for achieving these are not realistic, taking into account limited institutional capacities at the domestic level. The Report warns that 'it is time for African leaders to move away from signing treaties and developing action plans to delivery and implementation. ${ }^{89}$ The UNCTAD Report urges large and wealthy countries to demonstrate leadership in the integration process and set up a monitoring system showing to what extent members have implemented their obligations under the FTAs.

Apart from compliance problems, overlapping membership undermines effectiveness of FTAs. Out of 54 States, 42 are member of two or more FTAs, which each have established their own liberalization regime. Kenya is champion with its membership in four FTAs, including CEN-SAD, COMESA, EAC and IGAD. The overlapping membership may cause considerable complexities in tariff reduction schedules and implementing rules of origin and pose a heavy burden on the administration of customs. Overlapping membership may be explained by a lack of cooperation between FTAs and the desire of countries to gain better market access in more countries by joining two or more FTAs. Although multiple memberships may be acceptable in case of FTAs, it would be objectionable when one of the FTAs turns into a custom union. As the hallmark of a customs union is a commonly established common customs border (with commonly agreed tariffs and non-tariff import rules), it would be unacceptable for one of its members to join an FTA. ${ }^{90}$ Multiple memberships and shared loyalty towards FTAs may also cast doubt about the commitment for pursuing the objectives of a specific FTA.

In sum, there appears to be only five FTAs that make progress, albeit with different pace, towards integration as is anticipated by the AU. On 10 June 2015, COMESA, EAC and SADC launched the COMESA-EAC-SADC Tripartite Free Trade Area. ${ }^{91}$ The FTA represents 26 countries and covers trade in countries with a combined population of some 600 million people and a GDP of

\footnotetext{
89 ibid 6o.

9o Even if a member has done so in the past. South Africa, for example, entered into a FTA with the EU while being a member of the SACU. The Southern African Customs Union (SACU), established in 1910, consists of Botswana, Lesotho, Namibia, South Africa and Swaziland.

91 Tripartite Free Trade Area Agreement (n 56).
} 
about USD 1 trillion. The general objectives of the Tripartite Free Trade Area are inter alia to create a large single market with free movement of goods and services to promote intra-regional trade as well as to enhance the regional and continental integration processes..$^{92}$ Notably, the agreement recognizes the problem of overlapping membership as in intents 'to resolve the challenges of multiple membership.' More specific objectives refer to the further removal of barriers of trade in goods, the liberalization of trade in services and the facilitation of cross-border investment by creating a single investment area. The Tripartite Free Trade Area comes with 15 annexes further elaborating on non-tariff barriers, customs procedures, rules of origin, competition, technical standards, sanitary measures as well as a dispute settlement system. The annexes do no yet cover trade in services or the promotion and protection of foreign direct investment. The Guidelines for Negotiating the Tripartite Free Trade Area give further guidance. ${ }^{93}$ Principles for further integration are variable geometry, ${ }^{94}$ flexibility and special and differential treatment, building on the acquis of the existing FTAs, a single undertaking, substantial liberalization, MFN and national treatment, reciprocity and decision-making by consensus. Given its size and advanced legal framework the Tripartite Free Trade Area may well serve as a first step towards further integration and creation of the African Economic Community.

However, taking into account the overall picture of African FTAs, the progress towards integration shows a mixed picture. Whereas some FTAs show considerable integration, other FTAs are lagging behind, or are even dysfunctional. Decisive for successful integration is the political commitment and the creation of stable and effective institutions in each of the FTAs.

\section{Regionalism as the Third Way Alternative to Bilateralism and Multilateralism: African Experience in the Promotion and Protection of Foreign Investment}

After sketching the fragmented, underdeveloped and heterogeneous network of investment treaties currently in force in Africa (Part 2) and briefly describing

$92 \quad$ ibid arts $4(\mathrm{~b})$ and $(\mathrm{c})$.

93 Tripartite FTA Negotiating Principles, Processes and Institutional Framework (12 June 2011) <www.tralac.org/files/2011/o6/Annex-1-T-FTA-Negotiating-Principles-etc.pdf> accessed 17 February 2017.

94 'Means the principle of flexibility which allows for progression in cooperation amongst members in a larger integration scheme in a variety of areas and at different speeds'. 
the rise of regional economic integration (Parts 3 and 4), it is worth exploring whether and to what extent regionalism may contribute to create a simpler, modern and more coherent legal framework. ${ }^{95}$ From this perspective, this Part discusses the benefits offered, the results achieved and the challenges posed by the proliferation of regional investment treaties across Africa.

With the conclusion of a multilateral treaty on foreign investment remaining a rather remote possibility and the disaffection demonstrated by several States for BITs, investment treaties concluded within, by or between regional economic integration organizations have emerged as an increasingly important alternative - or a kind of 'third way' - to multilateralism and bilateralism. The phenomenon is not new, as regional agreements of this kind had already been concluded in the 1970 s and $1980 \mathrm{os} .{ }^{96}$ The novelties are the proliferation of these treaties and their increasing level of sophistication, both being particularly evident in Africa.

It must be immediately conceded that the conclusion of regional treaties may pose serious problems with regard to their overlapping application and their coordination, which ultimately may affect the legal certainty needed by both States and foreign investors. According to UNCTAD,

$[\mathrm{r}]$ ising regionalism in international investment policymaking presents a rare opportunity to rationalize the regime and create a more coherent, manageable and development-oriented set of investment policies. In reality, however, regionalism is moving in the opposite direction, effectively leading to a multiplication of treaty layers, making the network of international investment obligations even more complex and prone to overlap and inconsistency. ${ }^{97}$

Yet, the rise of regionalism calls for a balanced examination of the potential benefits and risks. The concern about the unintended consequences of the conclusion of regional treaties in terms of increased complexity, overlapping and inconsistency is well found, but any generalisation is hazardous - at least

95 See, in particular, Stephan W Schill and Marc Jacob, 'Trends in International Investment Agreements, 2010-2011: The Increasing Complexity of International Investment Law' in Karl P Sauvant (ed), Yearbook on International Investment Law \& Policy 2011-2012 (OUP 2013) 141; Leon Trakman and Nicola Ranieri (eds), Regionalism in International Investment Law (OUP 2013); Wolfgang Alschner, 'Regionalism and Overlap in Investment Treaty Law: Towards Consolidation or Contradiction?' (2014) 17 JIEL 271.

$96 \quad$ See reference supra nn 33 and 34 .

97 UNCTAD (n 6) 4 . 
in Africa. This is due to the rather fragmented and extremely irregular development of BITs within the regional organisation with partial or complete African membership. This point may be illustrated by comparing the case of the regional investment treaties concluded within the League of Arab States and the OIC with those concluded within ECOWAS and SADC.

In the case of the OIC Investment Agreement, ${ }^{98}$ it appears that 20 BITs are currently in force just between Egypt and other members of the organisation. ${ }^{99}$ In the case of the League of Arab States investment agreement, ${ }^{100}$ it appears that 15 BITs are currently in force just between Egypt and other members of the organisation. ${ }^{101}$ The situation is further complicated by the simultaneous participation in both organisations of 13 States that have a BIT in force with Egypt. Moreover, neither of the regional treaties nor the relevant BITs contains any clause on possible inconsistencies between the applicable treaties, with the exception of the BIT between Egypt and Albania, according to which rules more favourable to foreign investors under other instruments would prevail over those of the BIT. ${ }^{102}$ The almost complete silence of these treaties on their coordination may be expected to make their interpretation and application rather problematic.

The situation is radically different in the case of the investment treaties concluded within SADC ${ }^{103}$ and ECOWAS. ${ }^{104}$ Only four BITs are currently in force between members of the first organization. While the SADC Protocol does not contain any provision on the coordination with other treaties, BITs concluded between its members generally give ways to other treaty provisions to the extent the latter are more favourable to foreign investor. ${ }^{105}$ With regard to the

\footnotetext{
98 OIC Investment Agreement (n 33).

99 Albania, Algeria, Bahrein, Comoros, Jordan, Kazakhstan, Kuwait, Lebanon, Libya, Malaysia, Mali, Morocco, Oman, Qatar, Somalia, Sudan, Syria, Tunisia, Turkey and Turkmenistan.

100 Agreement on Investment and Free Movement of Arab Capital among Arab Countries (n 35).

101 Algeria, Bahrein, Comoros, Jordan, Kuwait, Lebanon, Libya, Morocco, Qatar, Somalia, Sudan, Syria, Tunisia, United Arab Emirates and Yemen.

102 Agreement between the Government of the Arab Republic of Egypt and the Government of the Republic of Albania for the Encouragement and Reciprocal Protection of Investments (signed 22 May 1993, entered into force 6 April 1994) art 11.

103 SADC Protocol (n 27).

104 ECOWAS Supplementary Act (n 28).

105 See, for instance, Investment Promotion and Protection Agreement between the Republic of Mozambique and the Republic of Mauritius (signed 14 February 1997, entered into force 26 May 2003) art 11(1).
} 
ECOWAS Supplementary Act, the BIT between Burkina Faso and Guinea is apparently the only one concluded between the members of the organisation. Importantly, the ECOWAS Supplementary Act imposes an obligation upon the parties to renegotiate within 24 months prior agreements containing provisions inconsistent with it as well as to ensure that future agreements are fully consistent with it. ${ }^{106}$

Keeping in mind that the problems sketched above related to the proliferation of investment treaties and the overlapping parties to them affect in quite different proportions regional investment treaties, possible inconsistencies have to be settled by resorting to the applicable rules and principles governing treaties, most prominently the lex specialis and lex posterior principles. Yet, the concerned organisations and their members may consider the conclusion of subsequent agreements susceptible of settling any possible conflict in the application of the relevant treaties, presumably in favour of the provisions contained in the regional ones. The solution adopted in the COMESA Agreement (not in force) may serve as a model. ${ }^{107}$

The need to consider devices to solve possible conflicts between different treaties is even more evident when regional investment treaties expressly

106 ECOWAS Supplementary Act (n 28) art 31(1) and (2). Interestingly, the Pan-African Investment Code (n 8) art 3 ('Relationship with other investment agreements') reads: '1. This Code does not affect rights and obligations of Member States deriving from any existing investment agreement. 2. Notwithstanding Paragraph 1, Member States may agree that this Code replaces the intra-African bilateral investment treaties (BITs) or investment chapters in intra-African trade agreements after a period of time determined by the Member States or after the termination period as set in the existing BITs and investment chapters in the trade agreements. 3. Member States and Regional Economic Communities (RECs) shall take into account as far as possible the provisions of this Code when entering into any new agreement with a third country in order to avoid any conflict between its present or future obligations under this Code and its obligations in the other agreement. 4. Member States may agree that in the case of a conflict between this Code and any intra-African BIT, investment chapter in any intra-African trade agreement, or regional investment arrangements, this Code shall take precedence' (emphases added).

107 COMESA Investment Agreement (n 28) art 32 reads in part: '1. This Agreement or any action taken under it shall not affect the rights and obligations of the Member States under existing agreements to which they are parties. 2. Nothing in this Agreement shall affect the rights of the Member States to enter into other agreements not contrary to the principles, objectives and terms of this Agreement. 3. In the event of inconsistency between this Agreement and such other agreements between Member States mentioned in para 2 of this Article, this Agreement shall prevail to the extent of the inconsistency, except as otherwise provided in this Agreement'. 
allow the parties to negotiate and continue to conclude BITs. ${ }^{108}$ Alternatively, the members of the regional treaties may accept to amend their BITs whenever this is necessary to avoid any inconsistency with the regional agreement, or even to progressively terminate their BITs in accordance with the terms of each of them.

The problems related to the proliferation of investment treaties and their overlap at the bilateral and regional levels notwithstanding, several benefits and advantages can be associated to the conclusion of regional treaties. In the first place, investment treaties concluded within, by or between blocks of States may significantly simplify the normative landscape. Consider for instance the conclusion of the ECOWAS Supplementary Act or the investment agreement that may be concluded between the EU and ECOWAS within the EU's EPA initiative. The first treaty is the equivalent of 105 BITs concluded between the 15 members of the organization. The second would be the equivalent of 420 BITs concluded between the members of the two organizations (currently 28 and 15 respectively).

Moreover, the development of investment treaties by regions is not simply a matter of numerical equivalence to BITs, or expediency in the negotiations and conclusion of these treaties. The most important advantage is the creation of a single set of rules applicable to foreign investment within a block of States or between States belonging to two blocks. The uniformity of treaty rules expedites the process of facilitation and harmonization underway in Africa as well as the conclusion of other treaties that may enhance foreign investment, such as agreements for the avoidance of double taxation. From this perspective, Article 17 of the SADC Protocol on intra-regional and extra-regional agreements for the avoidance of double taxation is a good example. ${ }^{109}$

On an even more practical level, regional agreements are beneficial for both host States and foreign investors. For the former, the implementation of a single regional treaty may be expected to be less complicated, less problematic and ultimately less resource-consuming compared to the implementation of a bunch of similar, but probably not identical BITs. The exchange of best practices as well as the coordination of common policies amongst the concerned States could further contribute to facilitate progressively the flow and

108 Most African regional investment agreements allow for the parallel existence of BITs, see UNCTAD (n 4) 106, Table III.5.

109 It reads: 'With a view to encouraging the movement of capital within the Region, particularly to the least-developed countries, State Parties undertake, in line with their undertakings as set out in Annex 3 (Co-operation in taxation and related matters), to conclude between themselves agreements for the avoidance of double taxation'. 
management of foreign investment in the region by reducing, simplifying and accelerating the related procedures and hindrances. Under Article 19 of the SADC Protocol on harmonisation of policies and laws, for instance,

State Parties shall pursue harmonisation with the objective of developing the region into a SADC investment zone, which shall, among others, include the harmonisation of investment regimes including policies, laws and practices in accordance with the best practices within the overall strategy towards regional integration.

It is worth noting that some investment treaties expressly provide for institutional commitments and arrangements intended to ensure the full implementation of the obligations they contain. In this respect, under Article 25 of the ECOWAS Supplementary Act on 'implementation of community rules on investment promotion and facilitation of investment', the Community 'shall create regional structures for the implementation of the Community Investment Rules Member States in the area of the promotion and the facilitation of investment.'

The SADC Protocol is more sophisticated as it foresees a role for the relevant institutions of member States and in particular for the investment promotion agencies which shall

(a) carry out their investment promotion activities, in line with their national and regional development priorities;

(b) advise the Government of that State Party, the private sector and other stakeholders in the formulation and review of policies and procedures that affect investment and trade; and

(c) increase awareness of their investment incentives, opportunities, legislation, practices, major events affecting investments and other relevant activities through regular exchange of information. ${ }^{110}$

The SADC Protocol also requires that the Secretariat of the organization 'ensure[s] close collaboration with State Parties and all relevant institutions on investment and other related matters in the Region.'111

For foreign investors, a regional treaty would mean the possibility to invest across the territory of the regional organization and enjoy the same treaty protection. This would be translated into higher mobility within such a territory,

110 SADC Protocol (n 27), art 23.

111 ECOWAS Supplementary Act (n 28), art 23. 
easier development of investment projects in different States, more predictability and stability, and lower costs. The combination of all these elements may be expected to improve the competitiveness of foreign investors operating within the region.

The advantages of a regional treaty are magnified when the investment projects concerns more States, such as larges projects related to infrastructures, communications or in the field of energy exploitation or transportation. In the case of a transnational highway or pipeline, for instance, foreign investors will enjoy the same treaty protection with regard to the whole project. The regional treaty will not only enhance the stability and predictability of the legal framework, but also facilitate the implementation of, and compliance with, the relevant treaty provisions, including, if applicable, those related to transparency, consultations as well as social and environmental impact assessment.

Furthermore, from the standpoint of African States, the negotiation of investment treaties collectively within regional organizations may be expected to minimize the risks related to the race amongst individual States to attract foreign capital, which may lure them into increasingly heavy concessions and unduly incisive limitations to their capacity to protect public interests. Needless to say, the bargaining power of regional organizations ultimately hinges on the cohesiveness and commitment of its members.

This Section has confirmed the dynamism of African regional organizations. Against the background of an ambitious Pan African project, several organizations have offered important contributions to the promotion and protection of foreign investment in the continent. Although the proliferation of regional investment treaties and their overlap with bilateral treaties may, at least in the short term increase complexity and uncertainty, regionalism seems to impose itself as an important and effective alternative to bilateralism, especially if adequate techniques are developed and applied to avoid and settle conflicts. Regional agreements may become the cornerstones or building blocks of a simpler and more coherent legal framework for foreign investment for the benefit of the different stakeholders from the standpoint of both efficiency and predictability.

\section{Reconsidering the Promotion and Protection of Foreign Investment}

After discussing the rise of regionalism in Africa, it is time to look at the content of regional investment treaties. The next three sections will focus on how regional treaties in Africa have addressed three main concerns raised in 
relation to the substantive treaty protection of foreign investment, namely the unbalanced character of investment treaties (Section 6.1), the allegedly undue restrictions on the policy space of host States (Section 6.2) and the lack of transparency and public scrutiny which often characterize investment projects (Section 6.3). Indeed, several substantive provisions contained in African regional treaties offer innovative responses to these concerns.

\subsection{Balancing Rights and Obligations}

The first concern is the manifestly unbalanced character of the overwhelming majority of investment treaties. These treaties systematically provide a set of guarantees and rights to foreign investors, while imposing obligations exclusively on host States. ${ }^{112}$ It is worth pointing out that the Preamble of the PanAfrican Investment Code indicates amongst its objectives the achievement 'of an overall balance of the rights and obligations amongst Member States and the investors.' ${ }^{\prime 13}$ The content of investment treaties, as any other treaties, is the result of deliberate choices made by the contracting parties; even in some cases negotiators may have little or no bargaining power, or poor understanding of the implications and potential consequences of these treaties.

The ECOWAS Supplementary Act is a paradigmatic attempt to redress the unbalanced character of investment treaties. ${ }^{114}$ In the first place, Chapter II on standards of treatment of foreign investors is balanced by Chapter III on investor obligations and duties. In addition to the general obligations to respect local legislation and regulations, Article 11 imposes upon foreign investors the duty to provide upon request from the host State the information concerning the putative investment 'for purposes of decision-making in relation to that investment or solely for statistical purposes.' Chapter III also imposes specific substantial obligations upon foreign investors, including the obligations to carry out an environmental and social impact assessment of a putative investment (Article 12), to refrain from getting involved into any corruption practice

112 In Spyridon Roussalis v Romania, ICSID Case No ARB/o6/1, Award (7 December 2011) para 871 , the Tribunal conceded that ' $[\mathrm{t}]$ he BIT imposes no obligations on investors, only on contracting States'.

113 See Pan-African Investment Code (n 8). See also SADC, 'SADC Model Bilateral Investment Treaty Template with Commentary' (2012) preamble <www.iisd.org/itn/wp-content/ uploads/2012/10/sadc-model-bit-template-final.pdf $>$ accessed 17 February 2017.

114 Incidentally, Article $31(2)$ of the Supplementary Act provides that future agreements member States may enter into must be fully consistent with the 'balance of rights and obligations' it establishes. 
(Article 13), and to comply with relevant human rights and labour standard as well as with the principle of corporate social responsibility (Articles 14 to 16).

The ECOWAS Supplementary Act not only imposes upon foreign investors the substantive obligations mentioned above; it also attaches specific consequence in case of non-compliance. A dispute between the host State and a foreign investor on alleged violations of these obligations can be submitted by foreign investors to arbitration under Article 33, provided that an attempt to settle the dispute amicably has been unsuccessful. Furthermore, Article 18(1) introduces an innovative sanction for violations of the obligation on corruption imposed under Article 13. It establishes that a decision by a domestic court finding that an investor has breached Article 13 of the Supplementary Act would deprive the investor of the right to initiate any dispute settlement process established under the Supplementary Act. Interestingly, both the host State and the home State may raise this as an objection to jurisdiction in any dispute under the Supplementary Act (Article 18.1).

Article 29 of the ECOWAS Supplementary Act also imposes several obligations upon home States. Some of these obligations enhance the liability of foreign investors. They include a general obligation to ensure that the domestic legal systems and rules 'allow for, or do not prevent or unduly restrict, the bringing of court actions on their merits before domestic courts relating to the civil liability of investors for damages resulting from alleged acts or decisions made by investors in relation to their investments in the territory of other Member States.'115 The obligation paves the way to the institution of proceedings before the courts of the host State, a possibility which is often precluded by the forum non conveniens doctrine. What makes Article 29 even more interesting is the application in actions falling within the scope of Article 29 of the law of the host State.

Another obligation of host States is more specific and concerns corruption. Under Article 30(1), host States have to consider corruption, as precisely defined in sub-paragraphs (a) and (b), as a criminal offense and investigate, prosecute and punish with appropriate sanctions.

Finally, the investor's home State has an obligation to provide the potential host State, upon request, with the information necessary to the latter for the purpose 'to meet its obligations and perform its duties in relation to an investor or investment' under both the Supplementary Act and domestic law. ${ }^{116}$ This obligation complements the obligation incumbent upon the putative investor to provide the requested information to the host State.

115 ECOWAS Supplementary Act (n 28).

116 ibid art 28. 
All of these normative novelties confirm that there is nothing inherent in the unbalanced character of traditional investment treaties. Quite the contrary, investment treaties can be upgraded relatively easily, most prominently by introducing obligations for foreign investors and even their home States, as well as by adequately defining the rights and duties of both the home and host States. In this regard, the record of African regional organisations reveals a much evident readiness of States to move towards more 'modern' investment treaties in the framework of regional organisation as opposed to intra-African BITs. ${ }^{117}$ Regional agreements not only impose obligations and grant rights to the various stakeholders, but also combine them in a systematic manner with a view to ensure both an adequate protection to foreign investors and an appropriate level of control over their activities by both host and home States. What also emerges from the practice of regional investment treaties in Africa is certain openness towards the experience of organisations outside Africa, with the ECOWAS Protocol on energy being a fine example of normative cross contamination.

\subsection{Preserving Policy Space}

The content of African regional treaties must be appreciated also from the standpoint of the second concern mentioned above, namely risk that investment agreements could unduly limit the sovereignty of host States, curtail their regulatory powers and ultimately undermine their capacity to develop efficient policies, in particular in the field of the protection of the environment and public health. As pointed out in a recent document,

[o]ne common issue is the need to clarify the interaction between international investment instruments and domestic investment policy as well as policy in other areas - for e.g., sustainable development and environmental regulation. Governments must always be concerned about ensuring that there is sufficient policy space for them to engage in reconciling competing interests. ${ }^{118}$

117 African States have generally been rather reluctant to depart from the traditional model of BITs. Amongst the most recent BITs between African States, see for instance, the BIT between Egypt and Mali (whose Article 13 contains a general provision on security exceptions) and the BIT between Mali and Morocco, both concluded in 2014.

118 Commonwealth Investment Experts Group Meeting for the African Region, Kampala, October 2011, on file with the authors. 
It is undisputed that the host State exercises its legislative and regulatory powers with regard to all subjects - domestic or foreign - that are present within its jurisdiction. It is equally undisputed that foreign investors have to comply with local legislation and regulations. In this respect, it must be noted that some investment treaties impose amongst the general obligation incumbent upon foreign investors to comply with the law and regulations of the host State. For example, Article 11(1) and (2) of the ECOWAS Supplementary Act read:

1. Investors and Investments are subject to the laws and regulations of the host State.

2. Investors and investments must comply with the host State measures prescribing the formalities of establishing an investment, and accept host State jurisdiction with respect to the investment.

While the two paragraphs merely reiterate the obvious relationship between the host State and foreign investors, the reference to the 'acceptance' by the former of the jurisdiction of the latter seems redundant, if not misleading as it may suggest that the exercise of sovereign powers by the host State has somehow to be 'accepted' by foreign investors.

The crucial issue is that the host State's legislative and regulatory powers must be exercised in conformity with its international obligations, including those stemming from investment treaties. A prominent purpose of these treaties is indeed to define the limits within which these powers have to be exercised. The exercise of legislative and regulatory powers requires the balancing of the interests of all public and private stakeholders. From this perspective it must be emphasised that 'the principle that the State's exercise of its sovereign powers within the framework of its police power may cause economic damage to those subject to its powers as administrator without entitling them to any compensation whatsoever is undisputable. ${ }^{119}$

Appropriate clauses in investment treaties may ensure adequate regulatory space for administrative decision for the protection of the environment, public health, labour and human rights. This cannot, however, set aside the obligation to act diligently and transparently towards investors. Authorities cannot

119 Técnicas Medioambientales Tecmed, SA v Mexico, ICSID Case No ARB (AF)/oo/2, Award (29 May 2003) para 119. See also SD Myers $v$ Canada, UNCITRAL (NAFTA), First Partial Award (13 November 2000) para 285; Saluka v Czech Republic, Partial Award (17 March 2006) para 252; Parkerings-Compagniet AS v Lithuania, ICSID Case No ARB/05/8, Award (11 September 2007) para 332, and, with regard to indirect expropriation, Methanex Corporation v United States, NAFTA, Final Award (3 August 2005) pt IV, ch D, para 7. 
frustrate legitimate expectations, harass foreign investors or take arbitrary decisions. New generation investment treaties may therefore set higher normative standards for investors and, simultaneously, higher procedural standards for host States. Several arbitral awards have considered the arbitrariness of administrative decisions. ${ }^{120}$ Particularly in the context of Africa, the quality of administrative governance towards foreign investors has been a cause of concern. The UN Economic Commission of Africa has signalled general weaknesses in the African regulatory and institutional framework. Enforcement of business contracts in most African countries is 'often tedious, time consuming and expensive, giving little incentive to businesses, especially small ones, to use the courts to settle business disputes. Registration of property and applications for intellectual property rights are complex and costly administrative procedures.'121 An administrative environment that falls short of a minimum level of legal protection for investors may be more susceptible to investor's claims.

More than reiterating the right of the host State to exercise its legislative and regulatory powers, it is important that investment treaties define as precisely as possible the limits within which the host State action is to be considered as a legitimate exercise of these powers and therefore not exposed to a compensation claim by foreign investors. States have plenty of options to adequately safeguard their regulatory space. Different approaches have been adopted by ECOWAS, SADC and COMESA in their respective investment codes. In Article 20 (Maintenance of Environmental and other Standards) of the ECOWAS Supplementary Act, 'Member States recognize that it is inappropriate to encourage investment by relaxing domestic labour, public health, safety or environmental measures.' Article 21 (Minimum Standards for Environmental, Labour and Human Rights Protection) further clarifies the obligations of Member States and introduces the following catalogue:

1. Each Member State shall ensure that its laws and regulations provide for appropriate levels of environmental protection and shall strive to continue to improve those laws and regulations.

2. Each Member State shall ensure that its laws and regulations provide for high levels of labour and human rights protection appropriate to existing regional and international treaties that it enters into, and shall strive to continue to improve these laws and regulations.

\footnotetext{
120 Jacob Stone, 'Arbitrariness, the Fair and Equitable Treatment Standard, and the International Law of Investment' (2012) 25 Leiden JIL 77.

121 UNECA, Economic Commission for Africa, African Governance: Report II (OUP 2009).
} 
3. All Member States shall have a domestic social, health and environmental impact assessment laws that meet the minimum standards adopted by the Community on these matters.

4. All Member States shall ensure that their domestic laws and policies are consistent with the ILO Declaration on Fundamental Principles and Rights of Work, 1998.

5. All Member States shall ensure that their laws, policies and actions are consistent with the international human rights agreements to which they are a Party and at a minimum, with the list of human rights obligations and agreements already adopted.

Article 21 of the ECOWAS Supplementary Act safeguards the regulatory space of Member States by imposing upon them positive obligations with regard to environmental, human rights and labour standards. While the appropriate level of environmental protection is left in paragraph 1 to the concerned State, that of human rights and labour standard are defined also by the international treaties and instruments as indicated in paragraphs 4 and 5 . Paragraph 3 , finally, requires Member States to ensure that their domestic laws on social, health and environmental impact assessment are consistent with the standard adopted by ECOWAS.

Article 14 of the SADC Protocol takes a different approach. It precludes any violation of the treaty in relation to measures adopted to ensure that foreign investments are sensitive to health, safety or environmental concerns. It reads

Nothing in this Annex shall be construed as preventing a State Party from exercising its right to regulate in the public interest and to adopt, maintain or enforce any measure that it considers appropriate to ensure that investment activity is undertaken in a manner sensitive to health, safety or environmental concerns. ${ }^{122}$

The provision is self-judging, as clearly indicated by the text according to which it is for the host State to consider, in good faith, whether any given measure is appropriate to pursue this objective. Yet, the interpretation of the text may by more problematic when it comes to establish what is the precise meaning of the expression 'in a manner sensitive' to health, safety or environmental concerns.

The COMESA Agreement, in turn, contains a provision on general exceptions which provides that

122 SADC Protocol art 14 ('Right to regulate') (emphasis added). 
Subject to the requirement that such measures are not applied in a manner which would constitute a means of arbitrary or unjustifiable discrimination between investors where like conditions prevail, or a disguised restriction on investment flows, nothing in this Agreement shall be construed to prevent the adoption or enforcement by any Member State of measures:

(a) designed and applied to protect national security and public morals;

(b) designed and applied to protect human, animal or plant life or health;

(c) designed and applied to protect the environment; or

(d) any other measures as may from time to time be determined by a Member State, subject to approval by the CCIA Committee.

2. Nothing in this Agreement shall be construed to prevent a Member State from adopting, maintaining or enforcing any measure that it considers appropriate to ensure that investment activity in its territory is undertaken in a manner sensitive to the principles outlined in subparagraphs $1(\mathrm{a})$ to $(\mathrm{c}) .{ }^{123}$

The provision is inspired by Article XX GATT. The chapeau has replaced 'trade' with 'investment' and the text differs insofar, from Article XX GATT, as it refers to 'like conditions' instead of 'same conditions'. The rest of the provision presents two important departures from Article XX GATT. First, sub-paragraphs $1(\mathrm{a})-(\mathrm{c})$ concern measures 'designed and applied to' protect national security and public morals, human, animal or plant life or health; and the environment; whereas under the corresponding letters of Article XX GATT measures have to be 'necessary'. As maintained by the Tribunal in Continental $v$ Argentina with regard to Article XI of the United States-Argentina BIT, ${ }^{124}$ and in line with the jurisprudence of the WTO Appellate Body, the 'necessity test' implies

a process of weighing and balancing a series of factors which prominently include the contribution made by the compliance measure to the enforcement of the law or regulation at issue, the importance of the

\footnotetext{
123 COMESA Investment Agreement (n 28), art 29 (emphases added).

124 Continental Casualty Company v Argentina, ICSID Case No ARB/o3/9, Award (8 September 2008) para 194 .
} 
common interests or values protected by that law or regulation, and the accompanying impact of the law or regulation on imports or exports. ${ }^{125}$

By allowing Member States to adopt and enforce the measures 'designed and applied to' - rather than 'necessary to' protect national security and public morals, human, animal or plant life or health, and the environment, Article 22 of the COMESA Common Investment Area does not require any balancing exercise. It rather focuses on why and how the relevant measures have been conceived and implemented, provided that they are consistent with the chapeau. Any possible doubt as to the latitude left to the host State is dissipated by the second paragraph, which clearly leaves to the host State the assessment, in good faith, on whether the given measures are appropriate for the purpose of sub-paragraphs $1(a)-(\mathrm{c})$.

Article 20 of the COMESA Investment Agreement further safeguards the regulatory powers of the host State in the context of the concept of indirect expropriation. It reads:

Consistent with the right of states to regulate and the customary international law principles on police powers, bona fide regulatory measures taken by a Member State that are designed and applied to protect or enhance legitimate public welfare objectives, such as public health, safety and the environment, shall not constitute an indirect expropriation under this Article.

The provision is similar to the one adopted in BITs or Model BITs. ${ }^{126}$ Yet, it significantly differs from those insofar as it excludes that bona fide regulatory measures could amount to indirect expropriation, instead of introducing a strong presumption (except in rare circumstances) against the qualification of non-discriminatory measures as indirect expropriation.

Two further developments related to the environment need to be mentioned. On the one hand, from the standpoint of the investor, a key issue is

125 See, in particular, WTO, Korea-Measures Affecting Imports of Fresh, Chilled and Frozen Beef, WT/DS161/AB/R, WT/DS169/AB/R, Report of the Appellate Body (10 January 2001) para 164 .

126 United States Model BIT (2012) Annex B ('Expropriation') para 4(b) <https://ustr.gov/ sites/default/files/BIT\%2otext\%2ofor\%20ACIEP\%2oMeeting.pdf> accessed 26 February 2017 ('Except in rare circumstances, non-discriminatory regulatory actions by a Party that are designed and applied to protect legitimate public welfare objectives, such as public health, safety, and the environment, do not constitute indirect expropriations'). See also United States-Rwanda BIT (n 13), Annex B, para 4(b). 
the environmental impact that investments may have, especially in the field of natural resources and energy. As pointed out in Maffezini v Spain, '[e]nvironmental impact assessment procedure is basic for the adequate protection of the environment and the application of appropriate preventive measures. This is true, not only under Spanish and EU law, but also increasingly so under international law.'127 Indeed, a few years later, the International Court of Justice upheld the existence of 'a requirement under general international law to undertake an environmental impact assessment where there is a risk that the proposed industrial activity may have a significant adverse impact in a transboundary context, in particular, on a shared resource.'128

While it is still premature to maintain the existence of an obligation to undertake an environmental impact assessment beyond transboundary contexts or shared resources, nothing prevents contracting parties to commit their respective investors to produce an assessment on the impact their investment may be expected to have within the territory of the host State. Taking an important step, the ECOWAS Supplementary Act imposes upon foreign investors the obligation to conduct an environmental and social impact assessment of the potential investment. It reads:

Investors and Investments shall conduct an environmental and social impact assessment of the potential investment. Investors or the investments shall comply with environmental assessment screening criteria and assessment processes applicable to their proposed investments prior to their establishment, as required by the laws of the host Member State for such an investment or the laws of the home State for such an investment. The investor shall comply with the minimum standards on environmental and socio-cultural impact assessment and screening that the Member States shall adopt at the first meeting of the Parties, to the extent that these are applicable to the investment in question. ${ }^{129}$

127 Emilio Agustín Maffezini v Kingdom of Spain, ICSID Case No ARB/97/7, Award (13 November 2000) para 67.

128 Pulp Mills on the River Uruguay (Argentina v Uruguay) (Provisional Measures) [2006] ICJ Rep 113, para 105 .

129 ECOWAS Supplementary Act (n 28) art 12(1). Similarly, the Pan-African Investment Code (n 8) art 37(4) that 'Member States and investors shall carry out environmental impact assessment in relation to investment', but does not define the respective responsibilities of States and investors. For an example of legislation requiring EIA, see South Africa, National Environmental Management Act, 1998 (No 107 of 1998) <http://faolex.fao.org/ docs/pdf/safi8752.pdf>; Environment Impact Assessment Regulations (No R 892 of 2014) $<$ http://faolex.fao.org/docs/pdf/safi42066.pdf >. See also Mohammad A Bekhechi and Jean-Roger Mercier, 'The Legal and Regulatory Framework for Environmental Impact 
On the other hand, under Article 12(3) of the ECOWAS Supplementary Act investors and the host State authorities 'shall apply the precautionary principle to their environmental and social impact assessment.'130 The obligations of investors are completed by the duty to make the environmental and social impact assessment available to the local community.

In the same vein, Article 37(4) of the Pan-African Investment Code imposes upon both the home State and the investor the obligation to carry out an environmental impact assessment in relation to the planned investment, although it remains to be seen how the responsibility and costs to comply with this obligation will be allocated and coordinated between the States (without specifying whether the host State, the home State or both) and investors. The Code does not contain any reference to the precautionary principle, but provides that investors shall protect the environment and, when their activities cause damages to the environment, shall take reasonable restorative measures.

The SADC Protocol takes a more traditional approach. Reminiscent of the Preamble of the Treaty establishing the World Trade Organization, Article 12 (Optimal Use of Natural Resources) of the SADC Protocol proclaims that 'State Parties shall promote the use of their natural resources in a sustainable and an environmentally friendly manner.' Article 13 of the SADC Protocol, which must be read in conjunction with Article 14 on the right to regulate ${ }^{131}$ and is almost identical to Article 20 of the ECOWAS Supplementary Act, elaborates and substantiates this obligation. It reads:

State Parties recognise that it is inappropriate to encourage investment by relaxing domestic health, safety or environmental measures and agree not to waive or otherwise derogate from, international treaties they have ratified, or offer to waive or otherwise derogate from, such measures as an encouragement for the establishment, acquisition, expansion or retention in their territories, of an investment.

Assessments: A Study of Selected Countries in Sub-Saharan Africa' World Bank Law, Justice and Development Series (2002) ch $3<$ http://documents.worldbank.org/curated/ en/573451468002164226/pdf/multiopage.pdf > all accessed 17 February 2017.

130 Amongst the rare references to the precautionary principle in investment treaty, see art 19(1) of the ECT (n 49), which reads in part: 'In its policies and actions each Contracting Party shall strive to take precautionary measures to prevent or minimize environmental degradation'.

131 SADC Protocol (n 27). 
This Section has confirmed that properly safeguarding the policy space of the host State has been and continues to be a priority for African governments and organizations. It has also indicated that African regional investment treaties offer several normative devices in this respect, often inspired by noninvestment legal instruments and with varying degrees of deference to the sovereignty of the host State. States could be reassured that investment agreements do not necessarily undermine their capacity to pursue their social and economic policies as well as to meet their responsibilities to protect public interests, including public health.

\subsection{Transparency, Information and Public Participation and Scrutiny}

The third main concern about foreign investment to be discussed in this section relates to the (lack of) transparency, information, public participation and public scrutiny, which still characterize investment projects. The general silence of investment treaties on these matters has already attracted a good deal of criticism ${ }^{132}$ and induced States and international and organizations alike to take appropriate measures. ${ }^{133}$ The reaction of African regional organizations has been rather heterogeneous. The SADC Protocol contains a vague and laconic provision on transparency according to which 'State Parties shall promote and establish predictability, confidence, trust and integrity by adhering to and enforcing open and transparent policies, practices, regulations and procedures as they relate to investment.'134

The COMESA Common Investment Area, in turn, focuses on the transparency of the settlement of dispute between States as well as between States and foreign investors. Articles 27(3) and 28(5) of the COMESA Investment Agreement, require that in both types of disputes all documents, including the notice of intention to arbitrate, pleadings, evidence and decisions, are made available to the public. Moreover, under Articles 27(4) and 28(6) of the COMESA Investment Agreement, procedural and substantive oral hearings are to be open to the public.

A more sophisticated approach has been adopted by ECOWAS. As noted above, one of the most innovative features of the ECOWAS Supplementary Act is the imposition of obligation upon the host State, foreign investors and

\footnotetext{
132 See, for instance, Van Harten (n 64).

133 See, for instance, the 2012 United States Model BIT ( $\mathrm{n}$ 126) as well as UNCITRAL, 'Rules on Transparency in Treaty-Based Investor-State Arbitration' (effective as of 1 April 2014) <www.uncitral.org/uncitral/en/uncitral_texts/arbitration/2014Transparency.html> accessed 17 February 2017 .

134 SADC Protocol (n 27) art 8.
} 
the home State. This occurs in particular with regard to the set of coordinated obligations on information and transparency imposed by the Act, subject, when appropriate, to restriction necessary to protect confidential business information. According to Article 22 of the ECOWAS Supplementary Act, in particular, the host Member States 'shall make available to the public any investment contracts or agreements with an investor involved in the investment authorization process, subject to the release of confidential business information.' The provision is of great importance not only because it allows public scrutiny, but also because it is an effective measure to fight corruption.

The ECOWAS Supplementary Act also recognises that host States have the right to seek from any putative foreign investor and its home State information about 'its corporate governance history and its practice as an investor, including in its home State.'135 The aim of this provision is to provide host States with the information necessary to assess the trustworthiness, the responsibility and the business performance of investors in order to make the best possible informed decision.

The ECOWAS Supplementary Act also spells out the obligations incumbent upon putative foreign investors and their home States that correspond to the right of the host State. On the one hand, in addition to the duty mentioned above to make the results of the social and environmental impact assessment known to the local community, foreign investors have a duty of general character to provide upon request 'such information ... concerning the investment in question for purpose of decision-making in relation to that investment or solely for statistical purposes. ${ }^{\prime 136}$ On the other hand, Article 28 of the ECOWAS Supplementary Act provides:

(1) Home States shall, on request and in a timely manner, provide to a potential host State such information as is requested and available for the purposes of the host State to meet its obligations and perform its duties in relation to an investor or investment under this Supplementary Act and the host State's domestic law. Home States shall protect confidential business information in this regard.

(2) Home States shall, on request, and in a timely manner, provide information relevant to the home State standards that might apply under like circumstances to the investment proposed by its investor, including but not limited to the home State's environmental and social public health impact assessment process.

135 ECOWAS Supplementary Act (n 28) art 26.

136 ibid art 11(4). 
The combination of the set of provisions just mentioned offers the host State adequate guarantees with regard to the acquisition of the relevant information and a minimum of public scrutiny. Yet, the ECOWAS Supplementary Act leaves much to be desired from the point of view of the active participation of the population and the groups that may be exposed to the consequences of specific investment project, including indigenous peoples.

Similarly to the conclusions reached in the previous two sections, it appears that properly drafted treaty provisions may greatly improve the level of transparency, participation and public scrutiny of investment projects. From this perspective too, African regional investment treaties contain innovative yet perfectible provisions. Including these provisions in investment treaties may be expected not only to enhance the legitimacy of foreign investment, but also to improve their economic performance.

\section{Conclusions}

Regional economic integration in Africa can be described as a complex and innovative exercise. Across the continent, 54 States cooperate in eight major FTAs with varying size, scope and effectiveness. The different FTAs feature in a long term project of the AU aiming at fully integrating the African continent into a single economic bloc. ${ }^{137}$ In this process of economic integration, the protection of foreign investment plays a key role. Several regional organizations have contributed and still contribute to improving and upgrading the protection of foreign investment in Africa. The institutional structures of these organizations are rather different and the legal instruments they have concluded rather heterogeneous.

Yet, a few interesting features of the process of improving and upgrading the treaty protection of foreign investment are already evident and deserve attention. First, there is a clear trend towards the progressive abandonment of the traditional bilateral approach in favour of a legal framework built upon blocks of States. The regional approach may be expected to boost the flow of foreign investment to and across Africa by simplifying and harmonizing the normative environment, and by enhancing the effectiveness and mobility of multinational companies.

137 On the relationship between the AEC and African regional organizations, see Richard F Oppong, 'The African Union, the African Economic Community and Africa's Regional Economic Communities: Untangling a Complex Web’ (2010) 18 Afr J Intl Comp L 92. 
Second, the instruments adopted by African regional organizations can be seen as remarkable attempts to answer to some of the main concerns that have been raised with regard to the current regulation of foreign investment, namely the need to rebalance the rights and obligations of various stakeholders as well as to better preserve the host State's policy space. This has led to the introduction, in some regional agreements, of obligations incumbent upon foreign investors and their home States. With regard to the consequence of violations of these obligations by foreign investors, it is worth noting that in the ECOWAS Supplementary Act, a breach of the duties related to corruption may deprive foreign investors of the access to international arbitration. For the time being, however, disputes concerning alleged violations of the obligations imposed upon foreign investors remain outside the scope of arbitral clauses.

Third, from the point of view of subject matters, the various investment instruments adopted by African regional organization offer several innovative elements, especially as far as the protection of the environment (including the obligation to go through an environmental impact assessment), social and human rights, transparency and information, corruption, economic development, and corporate responsibility are concerned. It can be safely concluded that African regional organizations and their member States have contributed in a significant and original way to upgrade investment treaties and bringing them in line with the rapid evolution and increasing complexity of international investment law. From this perspective, African regional organizations can be seen as an industrious normative laboratory on the promotion and legal protection of foreign investment. 